\title{
ANTHONY ANGELO AND THE COMPARATIVE LAW TRADITION
}

\section{Campbell McLachlan $Q C^{*}$}

Ici encore le droit comparé, c'est essentiellement la lutte contre les idées fausses et les préjugés, engendrés par l'attitude isolationniste qu'ont prise les juristes dans la plupart des pays. ${ }^{1}$

I first met Tony Angelo when I came up to Wellington from the South Island in 1981 to complete my law studies at Victoria. The Faculty at Victoria in that period comprehensively challenged the prevailing orthodoxy in many Commonwealth law schools, which was still characterised by what Lord Wilberforce had just castigated as "the austerity of tabulated legalism."2

Professors Robert Quentin Quentin-Baxter and Kenneth Keith were teaching Constitutional and Public International Law. The progressive reform of the law was being explored through many enticing honours seminars. The benefits of a generation of scholars who had experienced legal education in the United States, and had been determined to instil some of these fresh approaches throughout the Law School were there to be reaped by the students of the day. Amidst all of these opportunities, I signed up almost by chance for the class taught by Tony Angelo, simply called "Comparative Law."

The reading list was somewhat daunting. In the days before extensive photocopied student materials, we were expected to buy and read: John Merryman's The Civil Law Tradition, ${ }^{3}$ Amos \& Walton's Introduction to French Law, ${ }^{4}$ René David's Major Legal Systems in the World Today, ${ }^{5}$

* Professor of Law, Faculty of Law, Victoria University of Wellington.

1 René David Le Droit Comparé (Economica, Paris, 1982) 7.

2 Lord Wilberforce in Minister of Home Affairs v Fisher [1980] AC 319, 328 (HL), adopting the phrase of de Smith, The New Commonwealth and its Constitutions (Stevens, London, 1964) 194.

3 John Merryman's The Civil Law Tradition (Stanford University Press, Stanford, 1969).

4 F H Lawson, A E Anton and L Neville Brown Amos \& Walton's Introduction to French Law (3ed, Clarendon, Oxford, 1967).

5 René David and John Brierley Major Legal Systems in the World Today (2ed, Stevens \& Sons, London, 1978). 
and Noda's Introduction to Japanese Law - translated and edited by Tony Angelo himself. ${ }^{6}$ I still have all four books on my shelf today, having carried them to London for study and practice, and then back again to Wellington. Over the course of a full year's study, Tony patiently introduced us to the major legal families of the world, enlivening his account with his own rich experience in law reform in Mauritius and the Pacific Islands, amongst other places.

But the course offered the unwitting third year law student with something far more valuable than a Cook's Tour of exotic locations and legal norms. What Tony Angelo was really about was instilling in us the basics of the comparative method: how to step beyond the confines of our own Common Law legal system in order to understand and compare the different solutions adopted in other legal systems to the same problems. In so doing, he exposed, in René David's memorable phrase, the false ideas and preconceptions about other legal systems engendered by the isolationist attitude of lawyers in most countries.

Sometimes, this was a matter of demonstrating by careful analysis that what at first sight looked like major differences between legal systems were not true differences of substance at all. On other occasions, where there were real differences in approach, the comparison yielded a potentially rich source for law reform, as well as a deeper understanding of law as an expression of the diversity of human culture. By requiring us to look beyond the letter of foreign law to understand its underlying principles, Tony gave us the tools to understand foreign law. He also helped us to see that the Law itself could not be simply equated with the solutions currently adopted in the statutes or cases of any particular country, including our own.

For a student whose introduction to the law until that point had been somewhat Black Letter, this was inspiring. But it still left a central question unexplained. If the world was populated with a myriad of different national legal systems, what happened when, as a result of human interaction, these legal systems came into contact with each other, or even conflicted? Public International Law could supply a partial answer to this problem in its structures for the interaction of states. But it could not, and did not purport to, deal in detail with the many legal relationships between private persons which spanned national borders.

I began to find the answer to this problem, when I enrolled for Angelo's Masters seminar in "Comparative Conflict of Laws" the following year. Consider for a moment, if you will, the audacity of the very title of that seminar. Here we were in Wellington some 25 years ago studying the Conflict of Laws in comparative perspective. This was not simply a matter of examining the solutions adopted within the Common Law legal system to deal with foreign law problems. This subject was hard enough in itself. It had been expounded authoritatively since 1896 in Dicey's The

6 Yosiyuki Noda (trans and ed Anthony Angelo) Introduction to Japanese Law (University of Tokyo Press, Tokyo, 1976). 
Conflict of Laws, by then in its tenth edition. ${ }^{7}$ Its New Zealand variants had been the subject of ground-breaking work at Victoria by Don Inglis, published in $1959 .{ }^{8}$ Perhaps it was not quite as Dean Prosser had once famously put it, "a dismal swamp filled with quaking quagmires." ${ }^{9}$ But it retained a stubbornly arcane and difficult character. ${ }^{10}$

Yet, Angelo's Masters Seminar required us to understand not only our own system, but also the very different private international law solutions adopted in other countries. This took in the very different historical and procedural context of the application of foreign law in Civil Law countries; the American Revolution in the Conflict of Laws ${ }^{11}$ (the controversies engendered by which were still raging); and the efforts at international unification of conflicts rules led by The Hague Conference on Private International Law.

For me, this early exposure to Private International Law was like switching on a light bulb in a dark room. Suddenly, I began to see how the world's multitude of different legal systems might fit together. Private International Law offered the prospect of putting Comparative Law to work in the service of real-life legal relationships and problems which crossed borders. The key was to find a way of releasing conflict of law rules from their parochial bonds, so that they could better address global problems. ${ }^{12}$ Thus, the topic of my first published research was the case for New Zealand's membership of The Hague Conference on Private International Law ${ }^{13}$ (a step which the New Zealand Government eventually took in 2002).

The assistance which Tony Angelo gave me at this formative stage in my career was not simply in showing me the start of an intellectual road on which I have travelled ever since. He also gave me, as he has countless students, invaluable guidance as a mentor. He introduced me to Dr George Barton, sometime Dean of the Faculty and, by then, an eminent barrister, for whom I was privileged to work as a research assistant, or "devil". When the time came for me to consider what I should do for my Wanderjahre, Tony encouraged me to apply for scholarships for doctoral study overseas and to seek admission to the Summer Course at The Hague Academy of International Law. I attended the Academy as a student in July 1985, thus beginning a life-long association with it, both as

7 Morris et al (eds) Dicey and Morris on The Conflict of Laws (10ed, Stevens \& Sons Ltd, London, 1980).

8 Brinsley Donald Inglis Conflict of Laws (Sweet \& Maxwell, Wellington, 1959).

9 William Prosser Selected Topics on the Law of Torts (University of Michigan Press, Ann Arbor, 1953$) 89$.

10 On the state of the English Conflict of Laws at that time see Campbell McLachlan "International Litigation and the Reworking of the Conflict of Laws" (2004) 120 LQR 580, 582-586.

11 David Cavers The Choice-of-Law Process (University of Michigan Press, Ann Arbor, 1965).

12 Alexander Mills "The Private History of International Law" (2006) 55 ICLQ 1 cogently develops the international origins of Private International Law.

13 Campbell McLachlan "Reforming New Zealand's Conflicts Process: the Case for Internationalisation" (1984) 14 VUWLR 443. 
student, and latterly as teacher. ${ }^{14}$ I was also fortunate enough in the same year to work in the Legal Division of the Commonwealth Secretariat, then under the Directorship of another remarkable New Zealander, Jeremy Pope. Jeremy sent me to join Professor David McClean as Commonwealth Observer to The Hague Conference on Private International Law. In both of these formative experiences in The Hague, it was Tony's early introduction to comparative and international approaches to the conflict of laws which proved invaluable.

But the real significance of the intellectual debt which I owe to Tony's teaching came when I entered practice in England, working under Lawrence Collins, now a Lord Justice of Appeal, and then, as now, General Editor of Dicey. ${ }^{15}$ Our daily diet in practice was of cross-border cases, which integrally involved issues of the conflict of laws and, in turn, of foreign law. ${ }^{16}$ In this context, it suddenly became of great practical importance to be able to look beneath differences of nomenclature between legal rights and remedies in different countries. Sometimes, this might reveal a different route by which the same substantive relief could be obtained. Thus, disclosure of what had become of the fruits of a fraud, which might be possible in England as ancillary to a Mareva injunction, could be obtained in Switzerland by means of a criminal complaint. ${ }^{17}$ By contrast, in other cases, it might reveal a real difference in the applicable law which could greatly affect the parties' likely recovery - as, for example, where Saudi law, as the law applicable to a contract claim, precluded recovery for loss of expected future profits, a perfectly tenable head of damage in English law. ${ }^{18}$

Knowing how and when to use foreign law effectively was not a matter of seeking to retain the detail of foreign legal systems. Rather, it was the conflicts and comparative law method which provided the tools by which such problems could be analysed. These are not skills which can be easily acquired on the job. For lawyers who have been brought up exclusively within their own legal tradition, the notion that conflict of law rules might actually require the application of foreign law to a problem before them does not come naturally. For this reason, then, both Comparative Law and

14 Dip (cl) (1985); Director of Studies (Private International Law) (1996); Special Course "Lis Pendens in International Litigation" (2008).

15 The current edition, for which the author is a Specialist Editor, is Lawrence Collins et al (eds) Dicey, Morris \& Collins on the Conflict of Laws (14ed, Sweet \& Maxwell, London, 2006).

16 For example Libyan Arab Foreign Bank v Manufacturers Hanover Trust Co [1989] 1 Lloyd's Rep 608 (QB) (effect of US Libyan Sanctions Regulations on bank deposits in London), ISC Technologies Ltd v Guerin [1992] 2 Lloyd's Rep 430 (jurisdiction in fraud cases), Saab v Saudi American Bank [1999] 1 WLR 1861 (CA) (jurisdiction over foreign corporations).

17 Campbell McLachlan "The Jurisdictional Limits of Disclosure Orders in Transnational Fraud Litigation" (1998) 47 ICLQ 3, 29-33.

18 Saab v Saudi American Bank, above n 16 
the Conflict of Laws are subjects which are ideally suited to University study, as a means of preparing the young lawyer for international practice.

The process of globalisation has spawned a proliferation of courses on specific aspects of international private law, particularly in the context of international business transactions. In some fields, this reflects the achievement of unified rules or practices. Globalisation has also wrought important changes in the structure and priorities of the Conflict of Laws. But the world remains a world of separate states, with widely differing legal systems, traditions and cultures. As Angelo himself put it: ${ }^{19}$

Diversity is the source from which comparative lawyers extract their knowledge. That knowledge is the raw material from which their insights are drawn and from which the ideas for transplantation and crossfertilisation flow.

Our ever increasing global interdependence has if anything increased the need for rules which respect, and give effect to, those differences. For this purpose, conflicts rules have become more, rather than less necessary. As the Supreme Court of Canada put it in adopting a new rule for choice of law in tort, which would much more readily lead to the application of foreign law: ${ }^{20}$

If other states routinely applied their laws to activities taking place elsewhere, confusion would be the result. In our modern world of easy travel and with the emergence of a global economic order, chaotic situations would often result if the principle of territorial jurisdiction were not, at least generally, respected.

Thus, the task of equipping law students with foundational skills in comparative law and the conflict of laws is, if anything, even more urgently relevant today, than it was 25 years ago. So it is a particular pleasure to have the opportunity to thank Tony Angelo in the pages of this Review (to the editing of which he has devoted so much selfless labour over the years) for his work in passing on to me, as to many others, a living comparative law tradition. It was a delight to see this humane and hugely talented, but unduly self-effacing, scholar recognised by the French academic community for his contribution to comparative law scholarship by the award in 2004 of the Palmes Academiques (Chevalier).

19 Anthony Angelo "The Challenge of Diversity" in Ingeborg Schwenzer and Günter Hager (eds) Festschrift für Peter Schlechtriem zum 70. Geburtstag (Mohr Siebeck, Tübingen, 2003) 311.

20 Tolofson $v$ Jensen [1994] 3 SCR 1022. 
